\title{
Upregulation of astrocytic $\alpha 7$ nicotinic receptors in Alzheimer's disease brain- possible relevant to amyloid pathology
}

\author{
Wenfeng Yu*, Naguib Mechawar, Slavica Krantic, Jean-Guy Chabot, Rémi Quirion \\ From 2011 International Conference on Molecular Neurodegeneration \\ Shanghai, China. 22-24 September 2011
}

\section{Background}

Alzheimer's disease (AD) is characterized by extracellular deposits of $\beta$-amyloid $(A \beta)$, intracellular neurofibrillary tangles and inflammation response. The $\alpha 7$ nicotinic receptors (nAChRs) were proposed to be directly relevant to the pathogenesis of $\mathrm{AD}$ by interacting with $\mathrm{A} \beta$. The $\alpha 7$ $n A C h R s$ and $A \beta 1-42$ are co-localized in neuritic plaques and neurons and can form a high affinity stable complex. The up-regulation of $\alpha 7 \mathrm{nAChRs}$ on activated astrocytes has been reported in the AD brain. However, because of the poor specificity of currently available $\alpha 7 \mathrm{nAChR}$ antibodies, it is important to develop new ways to investigate the discrete distribution of $\alpha 7 \mathrm{nAChRs}$ in nervous tissue.

\section{Material and methods}

$\alpha 7 \mathrm{nAChR}$ single immunocytochemistry, double and triple-labeling immunocytochemistry were performed on formalin-fixed paraffin-embedded sections from 8 brain samples of neuropathologically confirmed sporadic AD and age-matched controls. Tissues were obtained from the Quebec Brain Bank (QBB; Douglas Institute, Montréal, QC, Canada). Immunohistochemical staining was performed as described previously (Yu et al., 2005). Primary cortical and hippocampal astrocytic cultures were prepared from the brains of newborn mouse (129S6 strain) according to the procedure of McCarthy and de Vellis (1980). The purified astrocytes were exposed to $100 \mathrm{nM}$ $\mathrm{A} \beta_{1-42}$ oligomers for $24 \mathrm{~h}$ at $37 \mathrm{C}$ with or without co-treatment with a series of concentration of PNU282987 and S24795 for $12 \mathrm{~h}$. To inhibit $\alpha 7 \mathrm{nAChR}$ activities, cells were pretreated with methyllycaconitine (MLA) for 45 min before $A \beta_{1-42}$ oligomers/PNU282987/S24795. After
$\mathrm{A} \beta_{1-42}$ treatments for 24 hours, the culture media were collected and was concentrated using Centricon YM-3 (Millipore, Temecula, CA). To prepare cell lysates, the treated cells were rinsed with $1 \times$ PBS, quick frozen then lysed on ice for $30 \mathrm{~min}$ in a lysis buffer. The lysates were then centrifuged at $10,000 \times g$ for $15 \mathrm{~min}$, and the supernatant was collected. Protein concentrations were determined and equalized before samples were applied to western blotting for measuring $A \beta$ oligomers.

\section{Results}

We successfully characterized the distribution of $\alpha 7$ $\mathrm{nAChRs}$ in AD brains using biotin conjugated $\alpha$-bungarotoxin. Our morphological data show the upregulation of $\alpha 7 \mathrm{nAChRs}$ in activated astrocytes in the AD brain. A certain proportion of $\alpha 7 \mathrm{nAChRs}$ positive astrocyes were morphologically associated with amyloid plaques. In mouse primary cultured astrocytes, treatments with different $\alpha 7$ nAChR agonists (PNU282987, S24795) significantly enhanced astrocytic $A \beta$ phagocytosis and inhibited $A \beta 1-42$ aggregation.

\section{Conclusion}

Take together, our study suggest that astrocytic $\alpha 7$ nAChRs possibly contribute to the initiation and development of amyloid pathology in the AD brain and thus should be considered as a potential therapeutic target, in addition to the better characterized neuronal nicotinic receptors.

\section{Acknowledgements}

Funded by CIHR \& FRSQ. 

receptors in Alzheimer's disease brain- possible relevant to amyloid pathology. Molecular Neurodegeneration 2012 7(Suppl 1):07.

Submit your next manuscript to BioMed Central and take full advantage of:

- Convenient online submission

- Thorough peer review

- No space constraints or color figure charges

- Immediate publication on acceptance

- Inclusion in PubMed, CAS, Scopus and Google Scholar

- Research which is freely available for redistribution 